\title{
Relationship Between CIP2A and Endometrium Cancer
}

\author{
Figen Aslann ${ }^{1}$, Gürhan Güney ${ }^{1}$, Ayla Solmaz Avcıkurt ${ }^{1}$, Mine Islimye Taşkın ${ }^{1}$ and Gizem Akkaş Akgün ${ }^{2}$ \\ ${ }^{1}$ Department of Gynecology, Balikesir University Medical Faculty, Cagis Yerleskesi, Bigadic Yolu 17. km Altieylul, Balikesir, Turkey \\ ${ }^{2}$ Department of Pathology, Dumlupinar University Medical Faculty, Istiklal, Okmeydani cd, Merkez/Kütahya, Turkey
}

\begin{abstract}
Objective: To determine whether there is a relationship between endometrium cancer and the oncoprotein cancerous inhibitor of protein phosphatase 2A (CIP2A).

Study Design: A descriptive study.

Place and Duration of Study: Balıkesir University Medical Faculty Hospital, Balıkesir, Turkey, from January 2013 to July 2018.

Methodology: CIP2A was studied immunohistochemically and molecularly in paraffin blocks. The correlation between CIP2A expression and different endometrial pathologies were evaluated. In addition, the relationship between CIP2A expression in tumor tissue and clinicopathological prognostic parameters and also between Ki67, P53, HER2 with CIP2A expression were investigated.

Results: A higher expression of CIP2A was found in endometrium cancer tissues compared to normal endometrial tissues. In addition, CIP2A expression according to molecular and immunohistochemical results was associated with significant poor prognostic factors such as FIGO Stage, FIGO Grade, cervical involvement, myometrial invasion and HER2 positivity.

Conclusion: CIP2A could be a promising and therapeutic target in endometrium cancer. Invention of the complex connections of CIP2A with other oncoproteins may lead to amazing and interesting developments in both early diagnosis and treatment.
\end{abstract}

Key Words: CIP2A, Endometrium cancer, Expression, Oncoprotein.

How to cite this article: Aslan F, Güney G, Avcıkurt AS, Taşkın MI, Akgün GA. Relationship Between CIP2A and Endometrium Cancer. J Coll Physicians Surg Pak 2020; 30(04):373-378. DOI: https://doi.org/10.29271/jcpsp.2020.04.373.

\section{INTRODUCTION}

Endometrium cancer, as the most common gynecologic cancer, may not have risk factors such as endometrial thickness, obesity, PCOS (polycysctic ovary syndrome) and unopposed estrogen levels. Regardless of the stage or grade, unexpected decrease in mean total survival time has highlighted the need to discover new biological markers by focusing on cancer cell metabolism both in diagnosis and pathogenesis. ${ }^{1,2}$

In cancer cell metabolism, oncoproteins have important roles such as regulation or synthesis of proteins for cancer cell growth. Antibodies that can bind to these oncoproteins inside cancer cell constitutes the basics of current treatment modalities as they suppress cancer cell growth. There are many different oncogenes encoding for several oncoproteins. One of them is the cancerous inhibitor of protein phosphatase 2A (CIP2A). CIP2A inhibits, PP2A (protein phosphatase $2 \mathrm{~A}$ ) and stabilise MYC (Transcription factor p64) in human cancers. Oncoproteins such as E2F1 (E2F transcription factor 1 ) and AKT (protein kinase $B$ ) are phosphorylated by CIP2A. ${ }^{3}$

In some of the solid and hematological cancers overexpression of CIP2A were approved.

Correspondence to: Dr. Figen Aslan, Department of Pathology, Balikesir University Medical Faculty, Cagis Yerleskesi, Bigadic Yolu 17. km Altieylul, Balikesir 10145,

Turkey

E-mail: fgenaslan@gmail.com

Received: February 17, 2020; Revised: May 09, 2020;

Accepted: May 11, 2020

DOI: https://doi.org/10.29271/jcpsp.2020.04.373
As a result of clinical researches, CIP2A overexpression was shown as a poor prognostic sign in ovarian, gastric and tongue cancer. CIP2A appears to be an oncoprotein that is generally associated with higher tumorgrade and treatment resistance. ${ }^{4-6}$

It is a well-known fact that the most important treatment method for cancer is early diagnosis. When literature is examined, we have seen lots of studies about endometrial cancer, but no results could be reached for its etiology and early diagnosis. ${ }^{7}$ Identifying new molecular markers such as CIP2A for endometrial carcinoma by elucidating disease mechanisms may be a hope for future treatment models.

So, the aim of this study was to investigate whether there is any relationship between CIP2A oncoprotein in patients diagnosed with endometrial cancer.

\section{METHODOLOGY}

A total of 129 patients admitted to Balıkesir University Medical Faculty Hospital for endometrial sampling between 2013 and 2018 were considered for this descritive study. Fifty- five of these patients had endometrial adenocarcinoma, 33 had endometrial hyperplasia without atypia, 18 had atypical endometrial hyperplasia, and 23 had normal endometrium as a control group. All cases of endometrial carcinoma were selected from patients with endometrioid type adenocarcinoma, who did not receive chemoor radiotherapy prior to surgery.

Hematoxylin and eosin (H\&E) stained slides, paraffin blocks and pathology reports were retrospectively reviewed. Histological grading of endometrial carcinoma cases were based on the degree of glandulardifferentiation, inaccordance with the International Federation of Gynecology and Obstetrics (FIGO) in 2009. 
Clinicopathological parameters such as age, histologic grade, myometrial invasion, lymphatic invasion, lymph node involvement, cervical involvement, and FIGO stage for each endometrial carcinoma were recorded from patients cards.
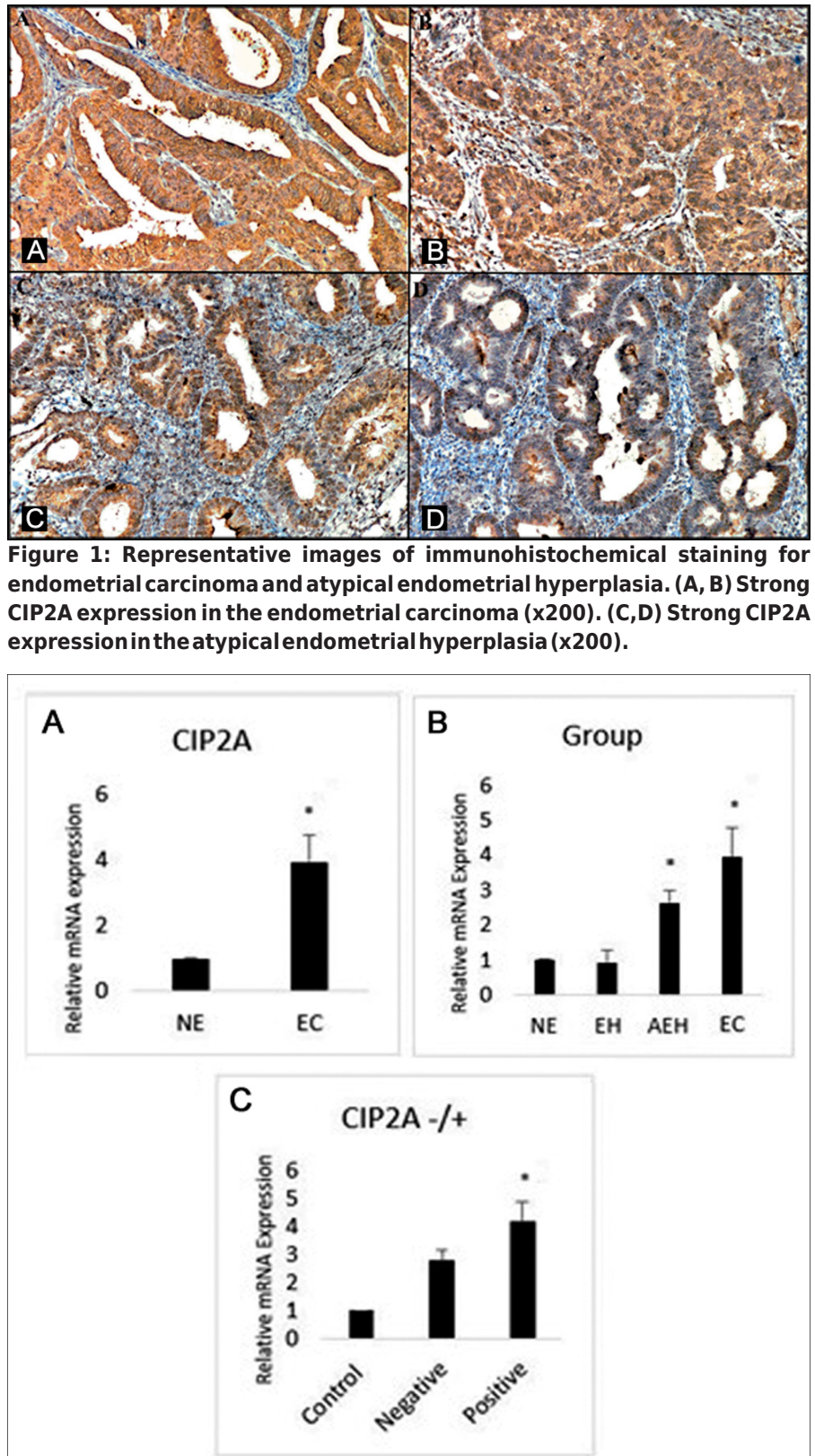

Figure 2: (A) Expression levels of CIP2A mRNA in normal endometrium and endometrial carcinoma. (B) The relationship between CIP2A mRNA expression and endometrial groups. (C) The relationship between CIP2A mRNA expression and CIP2A protein expression.

NE: Normal endometrium, EH: Endometrial hyperplasia, AEH: Atypical endometrial hyperplasia, EC: Endometrial carcinoma.

CIP2A was studied immunohistochemically and molecularly in paraffin blocks. In addition, Ki67, P53 and HER2 (human epidermal growth factor receptor 2) expression was investigated immunohistochemically in endometrial cancer tissues. Four micron thick sections were taken from paraffin blocks and paraffin melting was performed withVentana Benchmark XT. After the CC1 (Cell Conditioner 1) solution was applied for antigen release, 7 min hydrogen peroxide was applied to mask the endogenous peroxidase. Primary antibodies CIP2A (Novus Biologicals - 1/40 dilution), HER2 (Cell Marque / RabMab - 1/50 dilution), Ki-67 (Dako
Flex - 1/100 dilution) and P53 (Dako Flex - 1/100 dilution) were dropped manually and incubated for 30 minutes duration. Ultra view universal DAB detection kit secondary antibody was administered for $10 \mathrm{~min}$ and staining was completed according to the instructions of the staining device (Ventana HX Bench Mark). The slides removed from the device were dehydrated with alcohol and transparented with xylene and covered with coverslip.

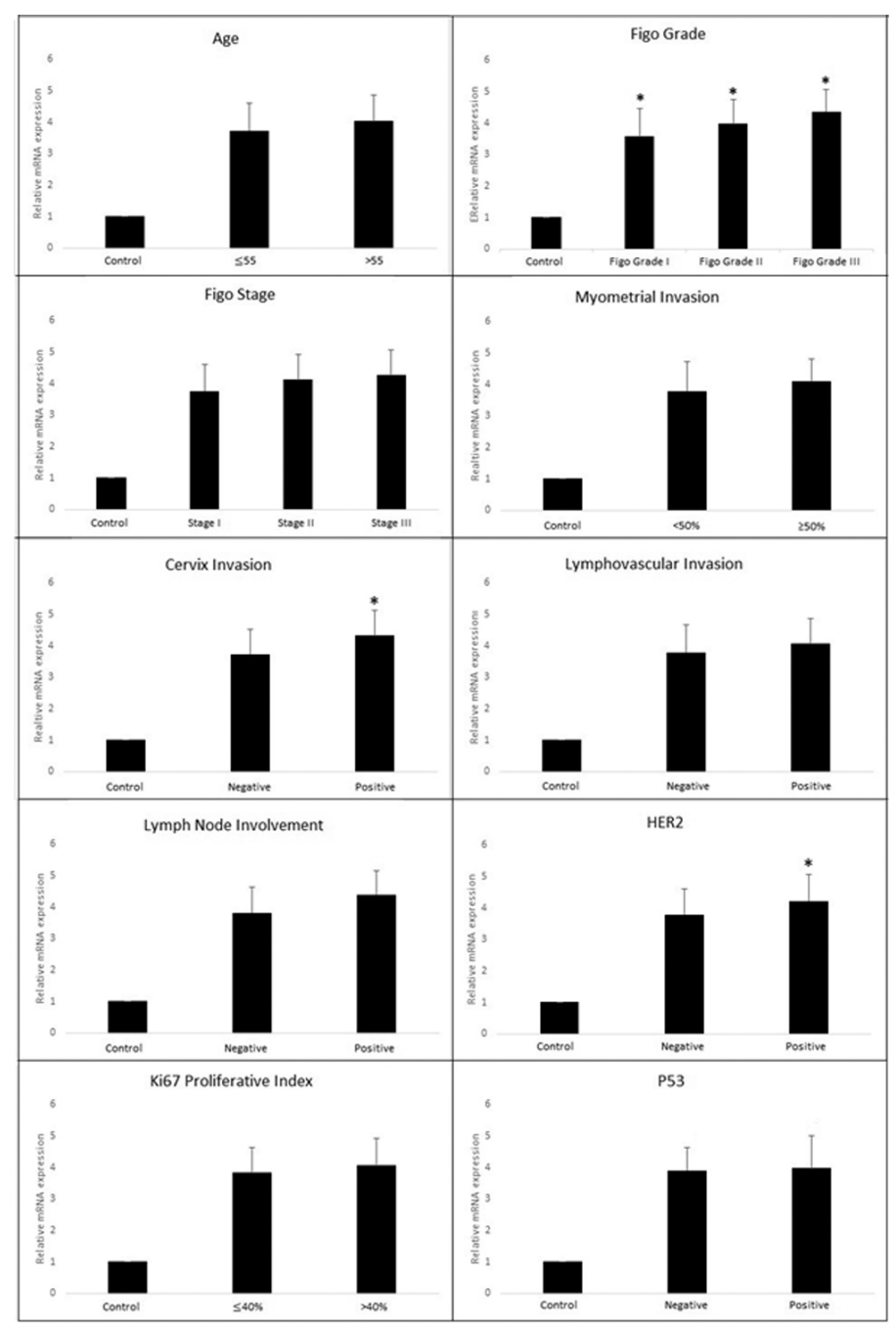

Figure 3: Relationship of CIP2A mRNA expression with clinicopathological parameters.

The evaluation of immunohistochemical expressions of CIP2A, HER2, Ki67, and P53 were performed by two pathologists without any clinical and pathological information about the cases. For CIP2A, the degree of cytoplasmic staining of epithelial cells was considered. Stromal areas were not evaluated. CIP2A expression was scored semiquantitatively according to staining intensity and percentage of staining in tissues. According to staining intensity, if there was no staining 0 point, weak staining 1 point, moderate staining 2 point, and strong staining was graded as 3 point. According to the dispersion of staining, no staining was graded as '0', 10-25\% staining ' 1 ', 26-50\% staining ' 2 ', 51-75\% staining ' 3 ' and $76-100 \%$ staining ' 4 '. As a result, the staining score was $0-1$, negative (-), 2-5, low expression; and $\geq 6$ was recorded as high expression. $^{8}$

Immunohistochemical evaluation for HER2 was performed according to the recommendations of the American Society of Clinical Pathology (ASCO / CAP) for the evaluation of HER2 in breast 
cancer. ${ }^{9}$ HER2 immunostaining was considered positive when strong membranous staining (score $3+$ ) was observed in at least $30 \%$ of tumor cells. Brown nucleus staining was considered positive for Ki-67 and the percentage of positive cells were recorded. Immunohistochemical evaluation for P53 were accepted as positive expression, if there was $\geq 10 \%$ staining in the nuclei of tumor epithelial cells and with $\leq 10 \%$ staining or no staining were accepted as negative expression. ${ }^{10}$

Table I. Characteristics of CIP2A expression in different endometrial groups.

\begin{tabular}{|l|c|c|c|}
\hline & $\begin{array}{c}\text { Negative } \\
\mathbf{n}(\%)\end{array}$ & $\begin{array}{c}\text { Low expression } \\
\mathbf{n}(\%)\end{array}$ & $\begin{array}{c}\text { High expression } \\
\mathbf{n}(\%)\end{array}$ \\
\hline $\begin{array}{l}\text { Endometrial carcinoma } \\
\mathrm{n}=55\end{array}$ & $9(16.36)$ & $18(32.73)$ & $28(50.91)$ \\
\hline $\begin{array}{l}\text { Atypical endometrial } \\
\text { hyperplasia } \\
\mathrm{n}=18\end{array}$ & $5(27.78)$ & $8(44.44)$ & $5(27.78)$ \\
\hline $\begin{array}{l}\text { Endometrial hyperplasia } \\
\mathrm{n}=33\end{array}$ & $19(57.58)$ & $12(36.36)$ & $2(6.06)$ \\
\hline $\begin{array}{l}\text { Normal endometrium } \\
\mathrm{n}=23\end{array}$ & $16(69.57)$ & $6(26.09)$ & $1(4.35)$ \\
\hline$* p<0.05$ & &
\end{tabular}

Table II. Expression of CIP2A in different endometrial groups.

\begin{tabular}{|l|c|c|c|}
\hline & $\begin{array}{c}\text { CIP2A (+) } \\
\mathbf{n}(\%)\end{array}$ & $\begin{array}{c}\text { CIP2A (-) } \\
\mathbf{n}(\%)\end{array}$ & p-value \\
\cline { 1 - 2 } $\begin{array}{l}\text { Endometrial carcinoma } \\
n=55\end{array}$ & $46(83.64)$ & $9(16.36)$ & \\
\cline { 1 - 2 } $\begin{array}{l}\text { Atypical endometrial hyperplasia } \\
n=18\end{array}$ & $13(72.22)$ & $5(27.78)$ & \multirow{2}{*}{$\leq 0.001$} \\
\cline { 1 - 2 } $\begin{array}{l}\text { Endometrial hyperplasia } \\
n=33\end{array}$ & $14(42.42)$ & $19(57.58)$ & \\
\cline { 1 - 2 } $\begin{array}{l}\text { Normal endometrium } \\
n=23\end{array}$ & $7(30.43)$ & $16(69.57)$ & \\
\hline
\end{tabular}

Total RNA isolation was obtained from the paraffin block of all patient groups using trizol reagent (Invitrogen, Carlsbad, CA, USA) kit according to the user protocol. Complementary DNA (cDNA) was transcribed from 100 ng of total RNA using a high-capacity cDNA reverse transcription kit (Applied Biosystems, Foster City, CA, USA), in a total volume of $20 \mu \mathrm{L}$. Reverse transcription (RT) master mix contained the following: $10 \times$ RT buffer, $25 \times$ dNTP (deoxynucleotide) mix (100 mM), $10 \times$ RT random primers, MultiScribe $^{\mathrm{TM}}$ reverse transcriptase, RNase inhibitor, and nuclease-free water. The RT reaction was performed in a thermocycler (Eppendorf, Hamburg, Germany) in the following conditions: 5 min at $25^{\circ} \mathrm{C}$, followed by 60 min at $42^{\circ} \mathrm{C}$, then the samples were heated to $70^{\circ} \mathrm{C}$ for $5 \mathrm{~min}$. The qPCR conditions were 45 seconds at $95^{\circ} \mathrm{C}$, followed by 40 cycles at $95^{\circ} \mathrm{C}$ for 10 seconds and $60^{\circ} \mathrm{C}$ for 45 seconds. Gene expression was assessed by normalising with the $2-\Delta \Delta C T$ method and the internal control gene $\beta$ actin according to $C T$ values. The following primers were used for amplification: CIP2A Forward 5-AAAGCGCGGCGAAAGCTAAA-3 and Reverse, 5-GCG TTCGCCTCTGACTTCAC-3. ACTB forward: 5' CCTGACTGACTACCTCATGAAGATCCTC 3'. Reverse: 5' CGTAGCACAGCTTCTCCTTAATGTCAC 3 '.

Table III. The relation between CIP2A expression and endometrial groups.

\begin{tabular}{|l|l|l|l|}
\hline & $\begin{array}{l}\text { CIP2A (+) } \\
\text { n (\%) }\end{array}$ & $\begin{array}{l}\text { CIP2A (-) } \\
\mathbf{n}(\%)\end{array}$ & p-value \\
\hline $\begin{array}{l}\text { Endometrial carcinoma } \\
\text { Normal endometrium }\end{array}$ & $\begin{array}{l}46(83.64) \\
7(30.43)\end{array}$ & $\begin{array}{l}9(16.36) \\
16(69.57)\end{array}$ & $\leq 0.001^{*}$ \\
\hline $\begin{array}{l}\text { Endometrial carcinoma } \\
\text { Endometrial hyperplasia }\end{array}$ & $\begin{array}{l}46(83.64) \\
14(42.42)\end{array}$ & $\begin{array}{l}9(16.36) \\
19(57.58)\end{array}$ & $\leq 0.001^{*}$ \\
\hline $\begin{array}{l}\text { Endometrial carcinoma } \\
\text { Atypical endometrial hyperplasia }\end{array}$ & $\begin{array}{l}46(83.64) \\
13(72.22)\end{array}$ & $\begin{array}{l}9(16.36) \\
5(27.78)\end{array}$ & 0.286 \\
\hline $\begin{array}{l}\text { Atypical endometrial hyperplasia } \\
\text { Normal endometrium }\end{array}$ & $\begin{array}{l}13(72.22) \\
7(30.43)\end{array}$ & $\begin{array}{l}5(27.78) \\
16(69.57)\end{array}$ & $0.012 *$ \\
\hline $\begin{array}{l}\text { Atypical endometrial hyperplasia } \\
\text { Endometrial hyperplasia }\end{array}$ & $\begin{array}{l}13(72.22) \\
14(42.42)\end{array}$ & $\begin{array}{l}5(27.78) \\
19(57.58)\end{array}$ & $0.077 *$ \\
\hline $\begin{array}{l}\text { Endometrial hyperplasia } \\
\text { Normal endometrium }\end{array}$ & $\begin{array}{l}14(42.42) \\
7(30.43)\end{array}$ & $\begin{array}{l}19(57.58) \\
16(69.57)\end{array}$ & 0.362 \\
\hline *p<0.05 & & \\
\hline
\end{tabular}

Table IV. Relationship of CIP2A protein expression with clinicopathological parameters.

\begin{tabular}{|c|c|c|c|}
\hline & $\begin{array}{l}\text { CIP2A (+) } \\
n=46(\%)\end{array}$ & $\begin{array}{l}\text { CIP2A (-) } \\
n=9(\%)\end{array}$ & p-value \\
\hline $\begin{array}{l}\text { Age } \\
\leq 55 \\
>55\end{array}$ & $\begin{array}{l}14(30.43) \\
32(69.57)\end{array}$ & $\begin{array}{l}3(33.33 \\
6(66.67)\end{array}$ & $>0.999$ \\
\hline $\begin{array}{l}\text { FIGO Grade } \\
\text { Grade I } \\
\text { Grade II } \\
\text { Grade III }\end{array}$ & $\begin{array}{l}13(28.26) \\
20(43.48) \\
13(28.26)\end{array}$ & $\begin{array}{c}5(55.56) \\
4(44.44) \\
0(0.00)\end{array}$ & 0.119 \\
\hline $\begin{array}{l}\text { FIGO Stage } \\
\text { Stage I } \\
\text { Stage II } \\
\text { Stage III-IV }\end{array}$ & $\begin{array}{c}20(43.48) \\
17(36.96) \\
9(19.57)\end{array}$ & $\begin{array}{l}8(88.89) \\
1(11.11) \\
0(0.00)\end{array}$ & $0.042 *$ \\
\hline $\begin{array}{l}\text { Myometrial invasion } \\
\geq 1 / 2 \\
<1 / 2\end{array}$ & $\begin{array}{l}25(54.35) \\
21(45.65)\end{array}$ & $\begin{array}{l}1(11.11) \\
8(88.89)\end{array}$ & $0.027 *$ \\
\hline $\begin{array}{l}\text { Cervix involvement } \\
\text { Present } \\
\text { Absent }\end{array}$ & $\begin{array}{l}19(41.30) \\
27(58.70)\end{array}$ & $\begin{array}{l}0(0.00) \\
9(100)\end{array}$ & $0.020 *$ \\
\hline $\begin{array}{l}\text { Lymphovascular invasion } \\
\text { Present } \\
\text { Absent }\end{array}$ & $\begin{array}{l}24(52.17) \\
22(47.83)\end{array}$ & $\begin{array}{l}5(55.56) \\
4(44.44)\end{array}$ & $>0.999$ \\
\hline $\begin{array}{l}\text { Lymph node metastasis } \\
\text { Present } \\
\text { Absent }\end{array}$ & $\begin{array}{l}11(23.91) \\
35(76.09)\end{array}$ & $\begin{array}{l}0(0.00) \\
9(100)\end{array}$ & 0.179 \\
\hline $\begin{array}{l}\text { HER2 } \\
\text { HER2(+) } \\
\text { HER2(-) }\end{array}$ & $\begin{array}{l}17(36.96) \\
29(63.04)\end{array}$ & $\begin{array}{l}2(22.22) \\
7(77.78)\end{array}$ & 0.473 \\
\hline $\begin{array}{l}\text { Ki67-Index } \\
>40 \% \\
\leq 40 \%\end{array}$ & $\begin{array}{l}22(47.83) \\
24(52.17)\end{array}$ & $\begin{array}{l}3(33.33) \\
6(66.67)\end{array}$ & 0.487 \\
\hline $\begin{array}{l}\text { P53 } \\
\text { P53(+) } \\
\text { P53(-) }\end{array}$ & $\begin{array}{l}15(32.61) \\
31(67.39)\end{array}$ & $\begin{array}{l}5(55.56) \\
4(44.44)\end{array}$ & 0.261 \\
\hline
\end{tabular}

The descriptive characteristics of the data were given as number, percentage and ratio. SPSS 25.0 statistical package version was used for analysis. Chi-square test for categorical variables, Fisher's corrected chi-square (Fisher Exact Test) and Chi-square on 
slope (Linear by Linear Assosiation) tests were applied. The $p$ $<0.05$ was accepted for significance. Normality of quantitative data was checked by Shapiro-Wilk test and found to be normally distributed therefore for statistical evaluation one-way ANOVA and the student t test was used. Data are presented as mean percent \pm SD. The $p$-level of $<0.05$ was accepted as statistically significant.

\section{RESULTS}

In our immunohistochemical study for 4 different endometrial groups, the results showed that CIP2A protein expression was higher in patients with endometrial carcinoma and atypical endometrial hyperplasia (Figure 1).

The highest CIP2A protein expression was in endometrial carcinoma patients. Table I shows the immunohistochemical staining characteristics of different groups. There was a statistically significant difference in CIP2A expression between the groups (Table II, $\mathrm{p} \leq 0.001)$

As shown in Table III, dual comparisons were also made between different endometrial groups for CIP2A expression. There was a significant difference in endometrial carcinoma cases when compared with the normal endometrium and endometrial hyperplasia in terms of CIP2A expression ( $p \leq 0.001$ and $p \leq 0.001$, respectively). Comparison of atypical endometrial hyperplasia with normal and endometrial hyperplasia showed a significant difference for CIP2A expression $(p=0.027$ and $p=0.042$, respectively). However, there was no significant difference between endometrial carcinoma and atypical endometrial hyperplasia cases and endometrial hyperplasia and normal endometrial cases in terms of CIP2A expression $(p=0.286$ and $p=0.362$, respectively).

According to the FIGO Stage, myometrial invasion and cervix involvement there was a positive correlation with CIP2A expression (Table IV). Age, FIGO Grade, lymphovascular space invasion, lymph node metastasis, HER2, P53 and Ki67-Index values were not statistically significant for CIP2A expression.

CIP2A mRNA level was measured by qRT-PCR and normalised to ACTB levels. The mRNA expression of CIP2A was significantly higher in endometrium cancer patients than in control tissues (Normal endometrium) ( $p \leq 0.001$ ) (Figure $2 A$ ). There was also a statistically significant difference between endometrial groups in terms of mRNA expression (Endometrial hyperplasia $=0.91$ \pm 0.36 , Atypical endometrial hyperplasia $=2.63 \pm 0.34$, Endometrial carcinoma $=3.93 \pm 0.83, p \leq 0.001$ ). Expression levels of CIP2A mRNA in atypical endometrial hyperplasia and tumor tissues were highercompared withcontroland endometrial hyperplasia tissues (Figure 2B). Moreover, CIP2A mRNA expression was higher too in the tumor group with positive CIP2A protein expression (CIP2A negative $=2.77 \pm 0.41$, CIP2A positive $=4.16 \pm 0.70$, $\mathrm{p} \leq 0.001$, Figure 2C).

When the relationship between CIP2A expression and clinicopathological parameters were examined, there was no significant difference in CIP2A expression with age $\left(\leq 55=3.73 \pm 0.87^{\prime} 55=\right.$ $4.02 \pm 0.82$ ) and different FIGO stages (Stage I = $3.76 \pm 0.84$, Stage $\|=4.13 \pm 0.79$, Stage $I I=4.19 \pm 0.80 ; p=0.248$ and $p=0.189$, respectively). However, there was a statistically signifi- cant difference between CIP2A expression and FIGO grade (FIGO grade $\mathrm{I}=3.58 \pm 0.88, \mathrm{FIGO}$ grade $\mathrm{II}=3.98 \pm 0.78, \mathrm{FIGO}$ grade $\mathrm{II}=$ $4.32 \pm 0.71, p=0.046$ ). In addition, there was no statistically significant difference in mRNA expression due to the state of prognostic parameters such as lymphovascular space invasion (Lenfovascular invasion negative $=3.80 \pm 0.87$, invasion positive $=4.05$ \pm 0.80 ), lymph node involvement (Lymph node negative $=3.83$ \pm 0.83 , Lymph node positive $=4.41 \pm 0.75)$, and myometrial invasion (Myometrial invasion $\geq 50 \%=4.08 \pm 0.68$, Myometrial invasion $<50 \%=3.79 \pm 0.94, p=0.286, p=0.066$ and $p=0.197$, respectively). However, in positive cervical invasion cases, CIP2A mRNA expression levels were statistically significantly higher than the negative invasion group (Cervical invasion negative $=3.73$ \pm 0.79 , cervical invasion positive $=4.30 \pm 0.80, p=0.015$ ).

Immunohistochemically in HER2 positive patients, CIP2A mRNA expression increased statistically significantly (HER2 negative $=$ $3.77 \pm 0.80$, HER2 positive $=4.23 \pm 0.84)(p=0.049)$. However, there was no relationship between CIP2A expression and P53 expression (P53 positive $=3.99 \pm 1.02$, P53 negative $=3.90$ $\pm 0.72, p=0.699)$, Ki67 proliferative index (Ki67 $\leq 40 \%=3.84$ \pm 0.82 , Ki67 $>40 \%=4.04 \pm 0.86, p=0.365)$. The quantitative distribution of the CIP2A mRNA expression among the prognostic parameters is presented in Figure 3.

\section{DISCUSSION}

In the present study, higher CIP2A expression was seen in endometrium cancer tissues compared to normal endometrial tissues. In addition, CIP2A expression according to molecular and immunohistochemical results was associated with significant poor prognostic factors such as FIGO Stage, FIGO Grade, cervical involvement, myometrial invasion and HER2 positivity.

As HER2 is an oncoprotein like CIP2A, its overexpression may have result in abnormal cell proliferation, formation of tumor blood vessels viavascularendothelial growthfactorand vascularpermeability factor, it may play a role in endometrium cancer. In a study with 110 cases of endometrial cancer, HER2 was shown to correlate only with histological grade when compared to age, clinical stage, histological type or the depth of myometrial invasion. ${ }^{11}$ In another study performed by Xiao et al., HER2 were associated with clinical stage, histological grade and lymph node metastasis in endometrium cancer cases. They also showed that endometrium cancers with FIGO stages III-IV, grade G2-3, deeper invasion and lymphovascular invasion had higher HER2 expression. ${ }^{12}$ In this study, CIP2A mRNA expression was statistically significantly higher in HER2 positive patients. Therefore, the results of both studies suggest that there may be a relationship between CIP2A and HER2, which we do not know the mechanism.

Molecular genetic alterations or inactivation of the p53 gene was blamed for endometrial cancer in so many studies. For example, Enomoto et al. investigated the role of p53 gene mutations in endometrial cancers and detected mutations in $23 \%$ of the cases. ${ }^{13}$ In a similar study made by Kiyoshi et al., 221 cases of endometrium cancer were studied and overexpression of $\mathrm{p} 53$ was found in 47 of 221 cases ( $21.3 \%$ ). They also claimed that $p 53$ overexpression has a statistically significant correlation with poor prognosis in early-stage disease. ${ }^{14}$ In this research, the P53 positive or negative endometrial cancers were not significantly 
different in terms of CIP2A expression. It is well known that CIP2A inhibits protein phosphatase 2A (PP2A) and transcriptional activity of $\mathrm{p} 53$ is regulated by PP $2 A .{ }^{15}$ Due to complex interactions between these enzymatic steps and relatively fewer number of cancer patients, it might be responsible for this result.

$\mathrm{Ki}-67$ is related to estrogen receptor content in the cyclic endometrium as a proliferation index. ${ }^{16}$ In this study, Ki67 proliferative index was not statistically significant between CIP2A positive and negative endometrium cancers. This may be due to the different estrogen receptor content in endometrium. Evaluation of the estrogen receptors may have found different results.

Parameters that may be a poor prognostic indicator in endometrial cancer such as Figo Stage, myometrial invasion and cervical involvement were significantly correlated with CIP2A protein expression in our study. ${ }^{17,18}$ In a study performed by Yu et al., CIP2A was overexpressed in endometrium cancer cases and strong relation with tumor grade, FIGO stage and cervix involvement, like in this study. They also found that Cyclin D1 regulates cell proliferation by preventing cells from progressing beyond the G1 control phase point and CIP2A depletion significantly downregulates cyclin D1 expression. Similar to Cyclin D1, the protein product of the P53 gene recognises damaged DNA in cells at the G1 point and prevents them from entering the cell division cycle. Considering the similarity of Cyclin D1 to P53, ${ }^{8,19,20}$ the same results were expected with the above study, but there was no significant relationship between P53 expression and CIP2A.

In addition, higher mRNA expression was observed in endometrial carcinoma and endometrial atypical hyperplasia cases compared to normal endometrial and endometrial hyperplasia cases. Since the CIP2A positivity in the literature was also associated with poor prognosis in other cancer types, our study was consistent with the literature. ${ }^{21,22}$

This study has some limitations. The small number of patients and the inability to follow whether the patients have chemotherapy-resistance, constitute the weakness of this study as CIP2A expression has been associated with drug resistance in other cancers in the literature. To the best of authors' knowledge, this is the first study investigating and comparing CIP2A levels in different endometrial pathologies with different molecular markers and that's why we believe this is the strongest part of our study.

\section{CONCLUSION}

CIP2A could be a promising and therapeutic target in endometrium cancer. Detection of the complex relationship of CIP2A with other oncoproteins may lead to exciting improvements in both early diagnosis and treatment; but we need lots of studies to understand the underlying molecular and cellular mechanisms of CIP2Ainendometrium cancer.

\section{FUNDING:}

This study was funded by Balıkesir University Coordinator of Scientific Research Projects.

\section{ETHICALAPPROVAL:}

This study was approved by the Institutional Ethical Committee of The Balıkesir Universty School of Medicine (Decision no:2018/97).

\section{CONFLICT OF INTEREST:}

Authors declared no conflict of interest.

\section{AUTHORS' CONTRIBUTION:}

FA, GG: Conception and design of the study.

FA, GG, ASA, MiT, GAA: Acquisition and analysis of data.

FA, GG, ASA: Drafting the manuscript or figures.

\section{REFERENCES}

1. Charo LM, Plaxe SC. Recent advances in endometrial cancer: a review of key clinical trials from 2015 to 2019. F1000Research 2019; 8: pii: F1000 Faculty Rev-849.

2. Makker V, Green AK, Wenham RM, Mutch D, Davidson B, Miller DS. New therapies for advanced, recurrent, and metastatic endometrial cancers. Gynecol Oncol Res Pract 2017; 4:19.

3. Soofiyani SR, Hejazi MS, Baradaran B. The role of CIP2A in cancer: a review and update. Biomed Pharmacother 2017; 96:626-33.

4. Li W, Ge Z, Liu C, Liu Z, Björkholm M, Jia J, et al. CIP2A is overexpressed in gastric cancer and its depletion leads to impaired clonogenicity, senescence, or differentiation of tumor cells. Clin Cancer Res 2008; 14:3722-28.

5. Khanna A, Pimanda JE, Westermarck J. Cancerous inhibitor of protein phosphatase $2 \mathrm{~A}$, an emerging human oncoprotein and a potential cancer therapy target. Cancer Res 2013; 73: 6548-53.

6. De P, Carlson J, Leyland-Jones B, Dey N. Oncogenic nexus of cancerous inhibitor of protein phosphatase 2A (CIP2A): an oncoprotein with many hands. Oncotarget 2014; 5:4581-602.

7. Costas L, Frias-Gomez J, Guardiola M, Benavente $Y$, Pineda M, Pavón MÁ, et al. New perspectives on screening and early detection of endometrial cancer. Int J Cancer 2019; 61: 129-32.

8. Yu N, Zhang T, Zhao D, Cao Z, Du J, Zhang Q. CIP2A is overexpressed in human endometrioid adenocarcinoma and regulates cell proliferation, invasion and apoptosis. Pathol Res Pract 2018; 214:233-9.

9. Wolff AC, Hammond MEH, Schwartz JN, Hagerty KL, Allred DC, Cote RJ, et al. American Society of Clinical Oncology/College of American Pathologists guideline recommendations for human epidermal growth factor receptor 2 testing in breast cancer. Arch Pathol Lab Med 2007; 131:18-43.

10. Obata T, Nakamura M, Mizumoto Y, lizuka T, Ono M, Terakawa J, et al. Dual expression of immunoreactive estrogen receptor $\beta$ and $p 53$ is a potential predictor of regional lymph node metastasis and postoperative recurrence in endometrial endometrioid carcinoma. PloS one 2017; 12:e0188641.

11. Morrison C, Zanagnolo V, Ramirez N, Cohn DE, Kelbick N, Copeland L, et al. HER-2 is an independent prognostic factor in endometrial cancer: Association with outcome in a large cohort of surgically staged patients. J Clin Oncol 2006; 24:2376-85

12. Xiao W, Dong $X$, Zhao H, Han S, Nie R, Zhang $X$, et al. Expression of MIF and c-erbB-2 in endometrial cancer. Mol Med Rep 2016; 13:3828-34.

13. Enomoto $T$, Fujita $M$, Inoue $M$, Rice JM, Nakajima RTO, Nomura $\mathrm{T}$, et al. Alterations of the p53 tumor suppressor gene and its association with activation of the cK-ras- 2 protooncogene in premalignant and malignant lesions of the human uterine endometrium. Cancer Res 1993; 53:1883-8. 
14. Ito K, Watanabe K, Nasim S, Sasano H, Sato S, Yajima A, et al. Prognostic significance of p53 overexpression in endometrial cancer. Cancer Res 1994; 54:4667-70.

15. Mumby M. PP2A: Unveiling a reluctant tumor suppressor. Cell 2007; 130:21-4.

16. Risberg B, Karlsson K, Abeler V, Lagrelius A, Davidson B, Karlsson MG. Dissociated expression of $\mathrm{BCl}-2$ and $\mathrm{Ki}-67$ in endometrial lesions: diagnostic and histogenetic implications. Int J Gynecol Pathol 2002; 21:155-60.

17. Hutt $S$, Tailor A, Ellis P, Michael A, Butler-Manuel S, Chatterjee J. The role of biomarkers in endometrial cancer and hyperplasia: A literature review. Acta Oncol 2019; 58:342-52.

18. Green Top Guildeline 67. Management of Endometrial Hyperplasia, Royal College of Obstetricians \& Gynaecologists 2016.
19. Masamha CP, Benbrook DM. Cyclin D1 degradation is sufficient to induce $\mathrm{Gl}$ cell cycle arrest despite constitutive expression of cyclin E2 in ovarian cancer cells. Cancer Res 2009; 69:6565-72.

20. Mateyak MK, Obaya AJ, Sedivy JM. c-Myc regulates cyclin DCdk4 and-Cdk6 activity but affects cell cycle progression at multiple independent points. Mol Cell Biol 1999; 19: 4672-83.

21. Li $Y$, Wang $M$, Zhu $X$, Cao $X$, Wu Y, Fang F. Prognostic significance of CIP2A in esophagogastric junction adenocarcinoma: A study of 65 patients and a meta-analysis. Dis Markers 2019; 2019:2312439.

22. Tang $M$, Shen JF, Li $P$, Zhou LN, Zeng $P$, Cui XX, et al. Prognostic significance of CIP2A expression in solid tumors: A meta-analysis. PloS One 2018; 13:e0199675. 